\title{
CD4 Count Pattern and Demographic Distribution of Treatment-Naïve HIV Patients in Lagos, Nigeria
}

\author{
Akinsegun Akinbami, ${ }^{1}$ Adedoyin Dosunmu, ${ }^{1}$ Adewumi Adediran, ${ }^{2}$ Sarah Ajibola, ${ }^{3}$ \\ Olajumoke Oshinaike, ${ }^{4}$ Kikelomo Wright, ${ }^{5}$ and Olanrewaju Arogundade ${ }^{1}$
}

\footnotetext{
${ }^{1}$ Department of Haematology and Blood Transfusion, College of Medicine, Lagos State University, Ikeja, PMB 21266, Lagos, Nigeria

${ }^{2}$ Department of Haematology and Blood Transfusion, Faculty of Clinical Sciences, College of Medicine, University of Lagos, PMB 12003, Idiaraba, Lagos, Nigeria

${ }^{3}$ Department of Haematology and Blood Transfusion, Lagos University Teaching Hospital, PMB 12003, Idiaraba, Lagos, Nigeria

${ }^{4}$ Department of Medicine, College of Medicine, Lagos State University, Ikeja, PMB 1266, Lagos, Nigeria

${ }^{5}$ Department of Community Health and Primary Health Care, College of Medicine, Lagos State University, Ikeja, PMB 21266, Lagos, Nigeria
}

Correspondence should be addressed to Akinsegun Akinbami, ajoke_clinic@yahoo.co.uk

Received 12 January 2012; Revised 24 August 2012; Accepted 26 August 2012

Academic Editor: Giuseppe Ippolito

Copyright ( $\odot 2012$ Akinsegun Akinbami et al. This is an open access article distributed under the Creative Commons Attribution License, which permits unrestricted use, distribution, and reproduction in any medium, provided the original work is properly cited.

\begin{abstract}
Background. CD4 count measures the degree of immunosuppression in HIV-positive patients. It is also used in deciding when to commence therapy, in staging the disease, and in determining treatment failure. Using the CD4 count, this study aimed at determining the percentage of HIV-positives who require antiretroviral therapy at enrollment in an HIV treatment and care centre. Methods. The Baseline CD4 count, age and gender of 4,042 HAART-naïve patients, who registered between December 2006 and June 2010, at Lagos State University Teaching Hospital, Ikeja, were retrospectively studied. Data were analyzed using SPSS version 16.0 (Statistical Package for Social Sciences, Inc., Chicago, Ill). Results. Patients consisted of 2507 (62\%) female and 1535 (38\%) males. The mean age of males was $37.73 \pm 9.48$ years and that of females $35.01 \pm 9.34$ years. Overall, the mean CD4 count was of $298.76 \pm 246.93$ cells $/ \mathrm{mm}^{3}$. The mean CD4 count of males was $268.05 \pm 230.44$ cells $/ \mathrm{mm}^{3}$ and that of females $317.55 \pm 254.72$ cells $/ \mathrm{mm}^{3}$. A total of $72.3 \%$ males, $64.3 \%$ females and $67.4 \%$ overall registered patients had CD 4 count $<350$ cells $/ \mathrm{mm}^{3}$, while only $15.1 \%$ males , $20.3 \%$ females, and $18.3 \%$ overall registered patients had CD4 count $>500$ cells $/ \mathrm{mm}^{3}$ at registration. Conclusion. Females account for more than half of registered patients in HIV clinic and have a relatively higher CD4 count than males. About three-quarter of HIV positives require antiretroviral therapy at registration.
\end{abstract}

\section{Introduction}

Worldwide Nigeria has the second highest number of new HIV/AIDS infections reported each year [1]. About 300,000 new infections occur annually with people aged $15-24$ years contributing $60 \%$ of the infections and 1.5 million people living with HIV require antiretroviral using the new WHO guidelines. Only about $30 \%$ of people living with HIV who need antiretroviral have access to it [2].

In 2009 an estimated $3.6 \%$ of 150 million Nigerians are living with HIV and AIDS [3]. Approximately 215,000 people died of HIV/AIDS in Nigeria in 2010 [4].
CD4 count measures the degree of immunosuppression in HIV-positive patients. There is an inverse relationship between CD4 count and degree of immunosuppression. CD4 count is used in monitoring disease progression, deciding when to commence therapy, staging the disease, determining treatment failure, and defining the risk for mother-to-child transmission.

Laboratory markers used in monitoring management in HIV-positive patients are HIV-RNA assay (Viral load) and CD4 count. The former is the gold standard, its use is, however, limited because of its cost and technology. Furthermore, there is a mismatch between an undetectable viral load 
$(<50$ copies $/ \mathrm{mL})$ and the absence of immune reconstitution, which can be confusing to both the treatment provider and patient.

Several studies have shown that CD4 count is the strongest predictor of disease progression and survival $[5,6]$. The cost of CD4 count is cheaper than viral load, it is increasingly becoming more affordable to patients in resource-poor countries $[7,8]$. All HIV-positive patients in resource rich and an increasing number of patients in resource-poor countries have baseline CD4 count on enrollment [9].

The CD4 cell count is the strongest predictor for risk of death and AIDS [10] at the time of initiating therapy, initiating highly active antiretroviral therapy (HAART) at higher CD4 cell counts has been demonstrated to "the risk of death, opportunistic infections and non-HIV related comorbidities" [11, 12]. Robert et al. [13] assessed CD4 count and the risk of death in HIV-infected patients on HAART, nearly all deaths occurred in patients with fewer than 50 CD4 cells $/ \mathrm{mm}^{3}$.

A common denominator amongst all the guidelines on initiating HAART in HIV-positive patients is the use of CD4 count in deciding when to initiate ART in HIVpositive patients. While some HIV-positive patients present at registration with low CD4 count, that is, less than 200 cells $/ \mathrm{mm}^{3}$ probably due to late presentation or diagnosis and are commenced on HAART almost immediately on enrollment irrespective of clinical symptoms. Some asymptomatic HIV-positive patients do not require antiretroviral (ART) drugs on enrollment because of their high CD4 count at registration hence their inability to meet criteria for initiation of therapy laid down by various organizations like World Health Organization (WHO), Centre for Disease Control, (CDC) Atlanta, Presidential Emergency Program for AIDS relief (PEPFER), Working Group of AIDS Research Advisory Council (OARAC), and European AIDS Clinical Society Guidelines, among others.

What is controversial is the optimal time to initiate antiretroviral therapy (ART). Various guidelines exist on the optimal time to initiate ART in adult asymptomatic patients. There seems to be consensus of opinion on deferral of ART in asymptomatic HIV patients whose CD4 count is greater than 500 cells $/ \mathrm{mm}^{3}$. However, the revised 2010, the World Health Organization (WHO) [14] recommended that all adult and adolescent including pregnant women with HIV infection presenting with CD4 count $\leq 350$ cells $/ \mathrm{mm}^{3}$, should start ART regardless of the presence and absence of clinical symptoms. Those with severe and advanced clinical disease (WHO clinical stage 3 and 4) should start ART irrespective of their CD4 cell count.

The U.S. Department of Health and Human Services (DHHS) [15] recommended that treatment of HIV infection shold be commenced, in patients with CD4 counts between 350 and 500 cells $/ \mathrm{mm}^{3}$. A randomized trial still in progress (START) [16] is randomizing people with a CD4 cell count of greater than 500 per $\mu \mathrm{L}$ to either start antiretroviral therapy (ART) immediately or defer to a CD4 cell count of 350 per $\mu$ L. However, Severe et al. [17] recommended that access to antiretroviral therapy should be expanded to include all HIV-infected adults who have CD4+ T-cell counts of less than 350 cells $/ \mathrm{mm}^{3}$ in those who live in areas with limited resources.

The U.S. Centre for Disease Control (CDC) and the prevention [18] staging system used the CD4 count as a tool to stage HIV into categories A, B, and C based on whether the CD4 count is $>500$ cells $/ \mathrm{mm}^{3}$, between $200-499$ cells $/ \mathrm{mm}^{3}$ and $<200$ cells $/ \mathrm{mm}^{3}$, respectively. It defines AIDS as all HIV-positive patients with CD4 count $<200$ cells $/ \mathrm{mm}^{3}$ or $\mathrm{CD} 4 \%<14 \%$. On the contrary, the WHO staging is based on clinical findings and does not require CD4 count in order to accommodate for resource-constrained settings where CD4 count testing may not be available.

CD4 count is an important tool in determining treatment failure in HIV-positive patients. The 2010 World Health Organization (WHO) [14] revised guideline defined immunological failure as a fall of CD4 count to baseline level or below, or $50 \%$ fall from on-treatment peak value or persistent CD4 count below 100 cells $/ \mathrm{mm}^{3}$. There must, however, be absence of concomitant infection to cause transient CD4 count decrease. A patient presenting with immunological or clinical failure (new or recurrent stage 4 disease) with viral load copies $>5000$ copies $/ \mathrm{mL}$ is deemed to have treatment failure and switched to second-line regimens [14].

The introduction of HAART as a modality of treatment in HIV positives has resulted in a dramatic decrease in AIDSrelated morbidity and mortality and a great improvement in CD4 count of patients [19]. In order to determine the true picture of CD4 count pattern in HIV positives, HAARTexperienced patients must, therefore, be excluded from the study. There is paucity of data on the pattern of CD4 count of HIV-positive, HAART-naïve patients at registration in Nigeria. The data may be used to determine the percentage of HIV-infected patients who require ART at registration. This will assist clinicians and policy makers in determining the point to begin treatment and the percentage of infected patients who require treatment at registration. Thus, this study aimed at determining the percentage of HIV positives who require treatment at enrollment using the $\mathrm{CD} 4$ count as a tool.

\section{Materials and Methods}

The records of 4,042 HAART-naïve, HIV-positive patients who registered at the HIV clinic of Lagos State University Teaching Hospital (LASUTH), Ikeja, between December 2006 and June 2010 were retrospectively reviewed.

Lagos is Nigeria most prosperous and arguably the most populous city. It has one of the highest standards of living as compared to other cities in Nigeria as well as Africa. All ethnic groups in Nigeria are well represented in Lagos because of its cosmopolitan constitution. LASUTH, the only teaching hospital owned by the State Government and one of the two in Lagos, is located in the state capital Ikeja. It serves as a referral centre to 26 other secondary (General) hospitals serving an estimated 17 million Lagosians.

Data retrieved included baseline CD4 count, age, and gender. All HAART-experienced, registered patients referred from other centers were excluded from the study. 
TABLE 1: Gender, age, and CD4 count frequency.

\begin{tabular}{cccc}
\hline Gender/Age & Male & Female & Overall \\
\hline Gender & $1535(4042)$ & $2507(4042)$ & 4042 \\
Age (years) & $38 \%$ & $62 \%$ & $100 \%$ \\
$15-30$ & $364(1535)$ & $954(2507)$ & $1318(4042)$ \\
& $23.7 \%$ & $38.1 \%$ & $32.6 \%$ \\
$31-50$ & $1035(1535)$ & $1379(2507)$ & $2414(4042)$ \\
& $67.4 \%$ & $55 \%$ & $59.7 \%$ \\
$>50$ & $136(1535)$ & $174(2507)$ & $310(4042)$ \\
& $8.9 \%$ & $6.9 \%$ & $7.7 \%$ \\
Mean age & $37.73 \pm 9.48$ & $35.01 \pm 9.34$ & $36.04 \pm 9.49$ \\
CD4 count & $268.05 \pm 230.44$ & $317.55 \pm 254.72$ & $298.76 \pm 93$ \\
cells/mm ${ }^{3}$ & & & \\
\hline
\end{tabular}

\section{Statistical Analysis}

Data were analyzed using SPSS version 16.0 (Statistical Package for Social Sciences, Inc., Chicago, Ill); a statistical computer software. The descriptive data were given as means \pm standard deviation (SD). The differences were considered to be statistically significant when the $P$ value obtained is less than 0.05 .

\section{Results}

Data from 4,042 registered patients were reviewed, consisting of 2507 (62\%) females and 1535 (38\%) males (Table 1). The overall minimum age was 15 years and the maximum 85 years with a mean of $36.04 \pm 9.49$ years (Table 1). A majority 2414 of $4042(59.7 \%)$ of all patients were between $31-50$ years, 1318 of $4042(32.6 \%)$ between $15-30$ years and only 310 of $4042(7.7 \%)$ were older than 50 years (Table 1$)$.

The minimum age for male was 15 years and the maximum of 85 years with a mean of $37.73 \pm 9.48$ years (Table 1). A majority of males, 1035 of 1535 (67.4\%) were between 31-50 years, 364 of 1535 (23.7\%) between 15-30 years and $136(8.9 \%)$ older than 50 years (Table 1$)$.

The minimum age for female was 15 years and the maximum 76 years with a mean of $35.01 \pm 9.34$ years (Table 2). The majority of females, 1379 of 2507 (55\%) were between 31-50 years, 954 of 2507 (38.1\%) between 15-30 years and 174 of 2507 (6.9\%) older than 50 years (Table 1 ).

Overall, the minimum CD4 count was 2 cells $/ \mathrm{mm}^{3}$ and the maximum 1868 cells $/ \mathrm{mm}^{3}$ with a mean of $298.76 \pm$ 246.93 cells $/ \mathrm{mm}^{3}$ (Table 2). Seven hundred and forty-one of $4042(18.3 \%)$ had CD4 count of $>500$ cells $/ \mathrm{mm}^{3}$ consisting of $414(55.8 \%)$ in the age group 31-50 years, 271 (36.57\%) between $15-30$ years and $56(7.55 \%)$ older than 50 years. While 3301 of $4042(81.7 \%)$ had CD4 count of $<500$ cells $/ \mathrm{mm}^{3}$, consisting of $578(14.3 \%)$ with CD4 count of between $350-500$ cells $/ \mathrm{mm}^{3}, 2723(67.4 \%)$ with CD4
$<350$ cells $/ \mathrm{mm}^{3}$ and 1712 (42.4\%) with CD4 count $<200$ cells $/ \mathrm{mm}^{3}$. Only 522 of $4042(12.9 \%)$ had CD4 count of $<50$ cells $/ \mathrm{mm}^{3}$. This consists of 319 of $522(61.1 \%)$ in the age group 31-50 years, $166(31.8 \%)$ between $15-30$ years, and $37(7 \%)$ older than 50 years (Table 2).

The minimum CD4 count for males was 3 cells $/ \mathrm{mm}^{3}$ and the maximum 1416 cells $/ \mathrm{mm}^{3}$ with a mean of $268.05 \pm 230.44$ cells $/ \mathrm{mm}^{3}$ (Table 2). A total of $233(15.1 \%)$ of 1535 male patients had CD4 count $>500$ cells $/ \mathrm{mm}^{3}$ consisting of 169 of $233(65.23 \%)$ between the age of $31-50$ years, $60(25.75 \%)$ between 15-30 years, and 21 (9\%) older than 50 years. The majority 1302 of 1535 (84.9\%) had CD4 count $<500$ cells $/ \mathrm{mm}^{3}$. A total of 193 of 1535 (12.6\%) had CD4 count between $350-500$ cells $/ \mathrm{mm}^{3}$, while 1109 of $1535(72.3 \%)$ had CD4 count $<350$ cells $/ \mathrm{mm}^{3}, 740$ of 1535 (48.3\%) with CD4 count $<200$ cells $/ \mathrm{mm}^{3}$. Only $245(16 \%)$ of males had CD4 count $<50$ cells $/ \mathrm{mm}^{3}$ consisting of $169(68.97 \%)$ between $31-$ 50 years, $51(20.81 \%)$ between $15-30$ years, and $25(10.2 \%)$ older than 50 years (Table 2); $P=0.528$.

The minimum CD4 count for females was 2 cells $/ \mathrm{mm}^{3}$ and the maximum of 1868 cells $/ \mathrm{mm}^{3}$ with a mean of $317.55 \pm$ 254.72 cells $/ \mathrm{mm}^{3}$ (Table 2). A total of 508 of 2507 (20.3\%) had CD4 count $>500$ cells $/ \mathrm{mm}^{3}$ consisting of 262 of 508 (51.57\%) between $31-50$ years, 211 of $508(41.53 \%)$ between $15-30$ years and $35(6.8 \%)$ older than 50 years. A total of 1999 of $2507(79.7 \%)$ females who had CD4 count $<500$ cells $/ \mathrm{mm}^{3}$ consisted of 385 of 2507 (15.4\%) with CD4 count of between $350-500$ cells $/ \mathrm{mm}^{3} 1614$ of 2507 (64.3\%) of females with CD4 count $<350$ cells $/ \mathrm{mm}^{3}$, and 972 of 2507 (38.77\%) with CD4 count $<200$ cells $/ \mathrm{mm}^{3}$. A total of 277 of $2507(11 \%)$ had CD4 count $<50$ cells $/ \mathrm{mm}^{3}$ consisting of 150 of $277(54.15 \%)$ between 31-50 years, 115 of 277 (41.51\%) between 15-30 years, and 12 of $277(4.3 \%)$ older than 50 years (Table 2); $P=0.039$.

\section{Discussion}

In Nigeria, the first case of HIV/AIDS was reported in 1986. HIV prevalence declined from $6 \%$ in 2001 to $4.3 \%$ in $2005,4.2 \%$ in 2008 , and $4.1 \%$ in 2010 . HIV response in Nigeria was health sector driven from 1986-1989,, but a multisectoral response commenced in 2000. Funding for the HIV response in Nigeria is obtained from both domestic (Federal Government of Nigeria, private sectors and state governments) and international sources like the U.S. Government, DFID, UN agencies, and global funds. It is pertinent to determinethe percentage of HIV-infected patients who require ART at registration vis-à-vis percentage benefiting from care services in order to appreciate progress made in reaching out to those in need of accessing care and treatment.

In Nigeria, prevalence among young women aged 1524 years is estimated to be three times higher than among men of the same age. Females constitute 58\% (about 1.72 million) of persons living with HIV in Nigeria and each year, 55\% of AIDS death occurs among women and girls [2] The female:male ratio in the present study of $1.6: 1$ is similar to 1.8:1 obtained by Omoti et al. [20] in Benin City, Nigeria. The disparity in gender prevalence is age dependent 
TABLE 2: CD4 counts distribution according to age and gender categories.

\begin{tabular}{|c|c|c|c|}
\hline Age categories (Years) & Male & Female & Overall \\
\hline \multicolumn{4}{|c|}{ CD4 counts cells $/ \mathrm{mm}^{3}$} \\
\hline & >500: 233 (1535) 15.2\% & 508 (2507) 20.3\% & $741(4042) 18.3 \%$ \\
\hline $15-30$ & 60 (233) 25.8\% & $211(508) 41.5 \%$ & $271(741) 36.6 \%$ \\
\hline $31-50$ & $169(233) 72.5 \%$ & $262(508) 51.6 \%$ & $431(741) 58.1 \%$ \\
\hline \multirow[t]{2}{*}{$>50$} & 21 (233) 9\% & 35 (508) 6.9\% & 53 (741) 7.2\% \\
\hline & <500: 1302 (1535) 84.8\% & 1999 (2507) 79.7\% & 3301 (4042) 81.7\% \\
\hline \multicolumn{4}{|c|}{ CD4 count ranges incells $/ \mathrm{mm}^{3}$} \\
\hline $350-500$ & 193 (1535) $12.6 \%$ & 385 (2507) $15.4 \%$ & 578 (3301) $17.5 \%$ \\
\hline$<350$ & 1109 (1535) 72.2\% & $1614(2507) 64.4 \%$ & 2723 (3301) 82.5\% \\
\hline$<200$ & 740 (1535) $48.2 \%$ & 972 (2507) 38.8\% & 1712 (3301) 51.9\% \\
\hline$<50$ & $245(1535) 16 \%$ & $277(2507) 11 \%$ & $522(3301) 15.8 \%$ \\
\hline
\end{tabular}

as reported by Glynn et al. [21] who reported HIV prevalence was six times higher in women than in men amongst sexually active 15-19 years old, but it drops to three times that in men among 20-24 years old and equal to that of men among 2549 years old. The present study did not consider age in groups in relation to gender and HIV status. However, 59.7\% of the studied population was between $31-50$ years, a ratio of $\mathrm{F}: \mathrm{M}$ of $1.6: 1$ obtained was, therefore, similar to $1: 1$ reported by Glynn et al. in those between 25-49 years. Generally, females are more predisposed to contracting HIV because of pregnancy or use of oral contraceptive, conditions which induced cervical ectopia in which there is replacement of squamous by columnar epithelium, thus increasing the risk of HIV infection for women 5-fold. Sexual intercourse during menstruation and presence of genital ulcer also increases the risk of HIV infection in females. Pelvic inflammatory disease predisposes to microulceration of the genital tract thus increasing risk of HIV infection. Culturally, the majority of males in this part of the world are circumcised, male circumcision affords some degree of protection, perhaps due to large numbers of langerhans cells in foreskin, so that the incidence of infection is reduced 8-fold over uncircumcised men [22]. Glynn reported that, despite all the predisposing factors in females, women married younger than men, and marriage was a risk factor for HIV, women often had older partners and men rarely had partners much older than themselves.

The mean ages of $35.01 \pm 9.34$ years and $37.73 \pm 9.48$ years for females and males, respectively, obtained in this study are similar to earlier study [21] of $34.41 \pm 8.87$ and $38 \pm 9.35$ for females and males, respectively, and also similar to 38 years reported by Omoti et al. [20] in both genders. This is understandably so because the majority of patients in HIV clinic are between 31-50 years being the age when sexual activity is at its peak.

This study reported mean CD4 counts in HAART-naïve, HIV positives of $268.05 \pm 230.44$ and $317.55 \pm 254.72$ cells $/ \mathrm{mm}^{3}$, respectively, for males and females and an overall mean of $298.76 \pm 246.93$ cells $/ \mathrm{mm}^{3}$. This could be compared with $303.16 \pm 234.32$ cells $/ \mathrm{mm}^{3}$ and $308.24 \pm 232.2$ cells $/ \mathrm{mm}^{3}$, respectively, for males and females and an overall mean CD4 count of $306.65 \pm 232.24$ cells $/ \mathrm{mm}^{3}$ reported by Akinbami et al. in an earlier study [23]. In both studies, females were found to a have a higher CD4 count than males.

Oladepo et al. [24] established in healthy Nigerian adults a reference value for CD4 of 365 to 1,571 cells $/ \mu \mathrm{L}$. with a mean CD 4 count of 847 cells/ $\mu \mathrm{L}$ similar to the mean value of 828 cells $/ \mu \mathrm{L}$ reported by Aina et al. [25] in an earlier study in Nigeria. Females were found to have significantly higher values of absolute CD4 counts in Oladepo's study in contrast to the earlier limited study by Aina et al. in Nigeria. This observation of higher CD4 count in females was also reported in several other countries among Nigerians [26], Ugandans [27], and Ethiopians [28]. A sex hormone effect is one possible explanation for the reported difference in CD4 counts between genders that has been suggested [28].

Using the 350 cells $/ \mathrm{mm}^{3}$ CD 4 count as cutoff from 2010 WHO [14] revised guideline for initiation of therapy in asymptomatic HIV patients, $72.3 \%$ males, $64.3 \%$ females and $67.4 \%$ overall registered patients require treatment on enrollment, while only $15.1 \%$ males, $20.3 \%$ females, and $18.3 \%$ overall registered patients with CD4 count $>500$ cells $/ \mathrm{mm}^{3}$ may require antiretroviral therapy deferral at registration.

In Sub-Saharan Africa, an estimated 10 million need treatment in 2010, only 5 million received it [1]. In Nigeria as at 2009 , only $31 \%$ of people living with HIV have access to care services [29], the government, through the National HIV/AIDS strategic framework for 2005-2009, set out to provide ARV to $80 \%$ of adults and children with advanced HIV infection and $80 \%$ of HIV-positive pregnant women, all by 2010 [30].

ARV treatment coverage in Nigeria remains low, the slow progress led to revising the strategic framework, and resetting treatment goals in its revised 2010-2015 framework [31]. By 2010, only a quarter of adults and $7 \%$ of children in need of treatment received it. Currently, 1.4 million adults and 262,000 children eligible for antiretroviral treatment remain without it [1].

In Africa, Botswana at the end of 2010 has the highest coverage rate around $93 \%$, other countries that have achieved more than $80 \%$ coverage are Rwanda and Namibia [1]. 
Access to antiretroviral therapy in Somalia is the lowest in Africa at 3\% while only $55 \%$ of those in need in South Africa are receiving it [32].

Cameroon, Cote d'Ivoire, Chad, Nigeria, and Ghana are some of the countries in Sub-Saharan Africa where between $20-39 \%$ of people requiring antiretroviral drugs are receiving them [1].

Being a retrospective study, some of the limitations of this study is the nonavailability of data on clinical manifestations of the patients, lack of data on records of distribution of the CD4 count, and percentage in need of treatment per year and lack of information on HIV risk factor, area of residence, family income, and marital status.

Extra efforts must be made by the Nigerian Government at all levels to meet the need of people living with HIV/AIDS eligible for treatment so as to reduce the spread of the pandemic.

\section{Conclusion}

About three-quarter of HIV positives require antiretroviral therapy at registration when 2010 WHO criteria are used for initiation of therapy, female population in HIV clinic is higher than males and the former has a relatively higher CD4 counts than the latter.

\section{Conflict of Interests}

There is no conflict of interest declared.

\section{Authors' Contribution}

A. A. Akinbami conceptualized, designed, and did data entry and analysis of the study. A. O. Dosunmu drafted the paper and revised it critically for important intellectual content. A. Adediran made substantial contributions to conception and design of the paper and reviewed it before final submission. S. O. Ajibola reviewed the paper critically for important intellectual content and gave final approval of the version to be published. K. O. Wright was involved in the drafting of the paper and reviewed it critically for important intellectual content. O. Oshinaike reviewed paper before final submission. O. Arogundade carried out the CD4 count assay.

\section{Acknowledgments}

The Institute of Human Virology Nigeria provided registration, laboratory investigations, and treatment free to all registered HIV patients used for this study. The authors are also grateful to Mr. Obadeyi Oluwaseun, the ICT (information and communication technology personnel) who retrieved the data used for the study.

\section{References}

[1] WHO, UNAIDS, and UNICE, 2011 Global HIV/AIDS response: epidemic update and health sector progress towards universal access, 2011.

[2] http://naca.gov.ng/.
[3] UNGASS, UNGASS Country Progress Report, Nigeria, 2010.

[4] HIV factsheet, http://photos.state.gov/libraries/nigeria/487468/publications/.

[5] S. C. Johnson and D. R. Kuritzikes, "Monitoring therapy with plasma HIV RNA and CD4 counts," HIV Advances in Research and Therapy, vol. 7, no. 1, pp. 3-8, 1997.

[6] M. Egger, M. May, G. Chêne et al., "Prognosis of HIV-1infected patients starting highly active antiretroviral therapy: a collaborative analysis of prospective studies," The Lancet, vol. 360, no. 9327, pp. 119-129, 2002.

[7] J. W. Mellors, A. Muñoz, J. V. Giorgi et al., "Plasma viral load and CD4+ lymphocytes as prognostic markers of HIV-1 infection," Annals of Internal Medicine, vol. 126, no. 12, pp. 946954, 1997.

[8] F. Lutwama, R. Serwadda, H. Mayanja-Kizza et al., "Evaluation of dynabeads and cytospheres compared with flow cytometry to enumerate CD4+ T cells in HIV-infected ugandans on antiretroviral therapy," Journal of Acquired Immune Deficiency Syndromes, vol. 48, no. 3, pp. 297-303, 2008.

[9] C. A. MacLennan, M. K. P. Liu, S. A. White et al., "Diagnostic accuracy and clinical utility of a simplified low cost method of counting CD4 cells with flow cytometry in Malawi: diagnostic accuracy study," British Medical Journal, vol. 335, no. 7612, pp. 190-194, 2007.

[10] Panel on Antiretroviral Guidelines for Adults and Adolescents. Guidelines for the Use of Antiretroviral Agents in HIV-1-Infected Adults and Adolescents, Department of Health and Human Services, 2008, http://www.aidsinfo.nih.gov/.

[11] M. May, J. A. C. Sterne, C. Sabin et al., "Prognosis of HIV1-infected patients up to 5 years after initiation of HAART: collaborative analysis of prospective studies," AIDS, vol. 21, no. 9, pp. 1185-1197, 2007.

[12] K. A. Lichtenstein, C. Armon, K. Buchacz et al., "Initiation of antiretroviral therapy at CD4 cell counts $\geq 350$ cells $/ \mathrm{mm}^{3}$ does not increase incidence or risk of peripheral neuropathy, anemia, or renal insufficiency," Journal of Acquired Immune Deficiency Syndromes, vol. 47, no. 1, pp. 27-35, 2008.

[13] R. Yarchoan, D. J. Venzon, J. M. Pluda et al., "CD4 count and the risk for death in patients infected with HIV receiving antiretroviral therapy," Annals of Internal Medicine, vol. 115, no. 3, pp. 184-189, 1991.

[14] World Health Organization, Antiretroviral Therapy for HIV infection in adults and adolescent Recommendation for public health approach, revision, 2010 .

[15] M. M. Kitahata, S. J. Gange, A. G. Abraham et al., "Effect of early versus deferred antiretroviral therapy for HIV on survival," The New England Journal of Medicine, vol. 360, no. 18 , pp. 1815-1826, 2009.

[16] INSIGHT START Trial, http://insight.ccbr.umn.edu/start/.

[17] P. Severe, M. A. J. Juste, A. Ambroise et al., "Early versus standard antiretroviral therapy for HIV-infected adults in Haiti," The New England Journal of Medicine, vol. 363, no. 3, pp. 257-265, 2010.

[18] Centers for Disease Control and Prevention, "1993 revised classification system for HIV infection and expanded surveillance case definition for AIDS among adolescents and adults," Morbidity and Mortality Weekly Report, vol. 41, no. RR-17, pp. 1-19, 1992, http://www.cdc.gov/mmwr/preview/ mmwrhtml/00018871.htm.

[19] F. J. J. Palella, K. M. Delaney, A. C. Moorman et al., "Declining morbidity and mortality among patients with advanced human immunodeficiency virus infection. HIV outpatient study investigators," The New England Journal of Medicine, vol. 338, no. 13, pp. 853-860, 1998. 
[20] C. E. Omoti, W. A. Udezi, R. E. Ediose et al., "Haematological aspects of antiretroviral naïve HIV patients in a Nigerian tertiary hospital: laboratory and clinical consideration," International Journal of Biological and Chemical Sciences, vol. 1, no. 2, pp. 176-180, 2007.

[21] J. R. Glynn, M. Caraël, B. Auvert et al., "Why do young women have a much higher prevalence of HIV than young men? A study in Kisumu, Kenya and Ndola, Zambia," AIDS, vol. 15, no. 4, pp. S51-S60, 2001.

[22] C. J. Miller, J. R. McGhee, and M. B. Gardner, "Mucosal immunity, HIV transmission, and AIDS," Laboratory Investigation, vol. 68 , no. 2, pp. 129-145, 1993.

[23] A. Akinbami, O. Oshinaike, T. Adeyemo, A. Adediran, O. Dosunmu et al., "Hematologic abnormalties in treatmentnaïve HIV patients," Infectious Diseases: Research and Treatment, vol. 3, pp. 45-49, 2010.

[24] D. K. Oladepo, E. O. Idigbe, R. A. Audu et al., "Establishment of reference values of CD4 and CD8 lymphocyte subsets in healthy Nigerian adults," Clinical and Vaccine Immunology, vol. 16, no. 9, pp. 1374-1377, 2009.

[25] O. Aina, J. Dadik, M. Charurat et al., "Reference values of CD4 $\mathrm{T}$ lymphocytes in human immunodeficiency virus-negative adult Nigerians," Clinical and Diagnostic Laboratory Immunology, vol. 12, no. 4, pp. 525-530, 2005.

[26] M. O. Njoku, N. D. Sirisena, J. A. Idoko, and D. Jelpe, "CD4+ T-lymphocyte counts in patients with human immunodeficiency virus type 1 (HIV-1) and healthy population in Jos, Nigeria," The Nigerian Postgraduate Medical Journal, vol. 10, no. 3, pp. 135-139, 2003.

[27] S. B. Tugume, E. M. Piwowar, T. Lutalo et al., "Hematological reference ranges among healthy Ugandans," Clinical and Diagnostic Laboratory Immunology, vol. 2, no. 2, pp. 233-235, 1995.

[28] M. Prins, J. R. Robertson, R. P. Brettle et al., "Do gender differences in CD4 cell counts matter?" AIDS, vol. 13, no. 17, pp. 2361-2364, 1999.

[29] WHO, UNAIDS, and UNICEF, “Towards Universal access: scaling up priority HIV/AIDS interventions in the health sector," 2010.

[30] WHO, UNAIDS, and UNICEF, “Towards Universal access: scaling up priority HIV/AIDS interventions in the health sector," 2007.

[31] National Agency for the control of AIDS (NACA), National HIV/AIDS Strategic Framework (NSF) 2010-2015, December 2009.

[32] UNAIDS 2008, Report on the global AIDS epidermic, Geneva, Switzerland, 2008. 


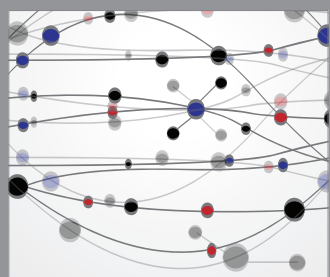

The Scientific World Journal
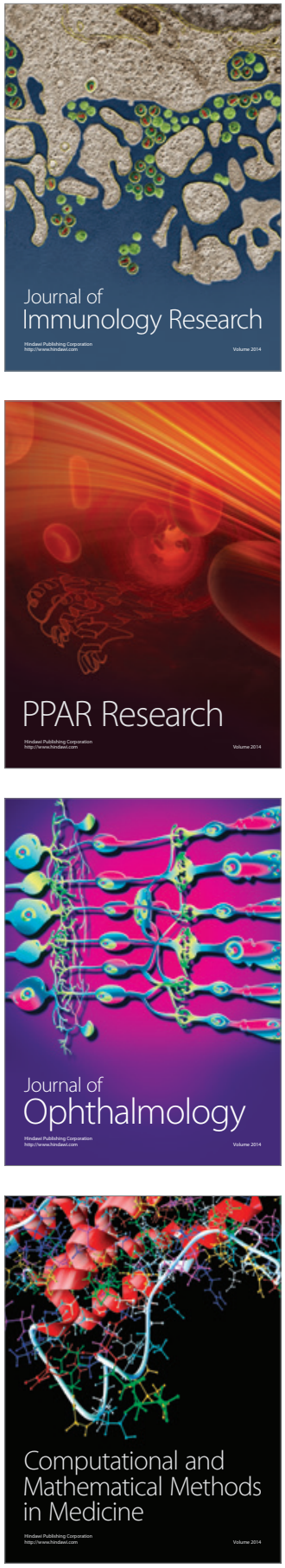

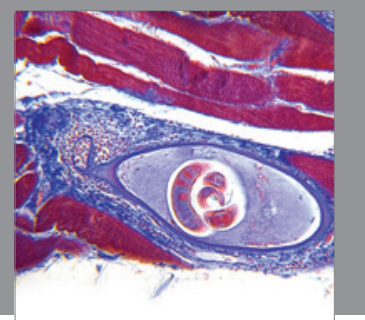

Gastroenterology

Research and Practice
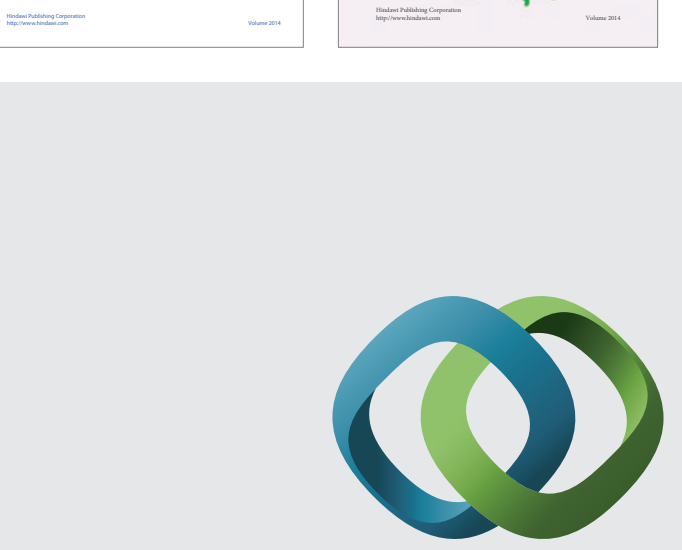

\section{Hindawi}

Submit your manuscripts at

http://www.hindawi.com
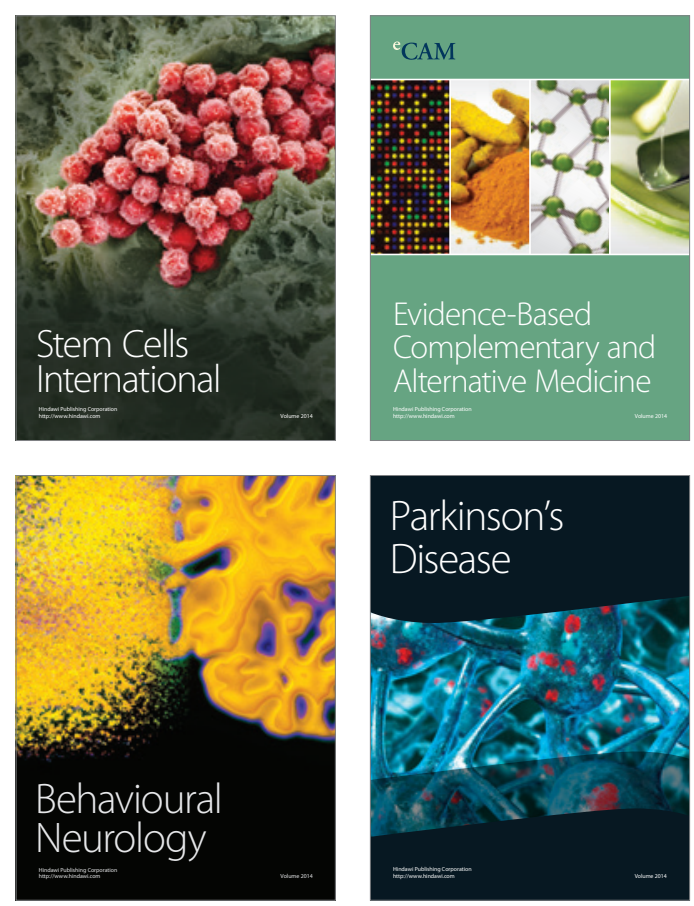

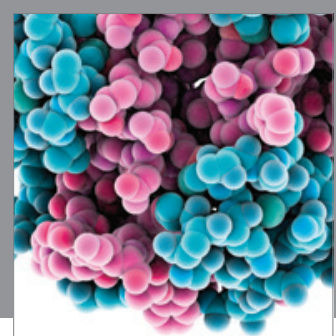

Journal of
Diabetes Research

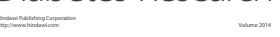

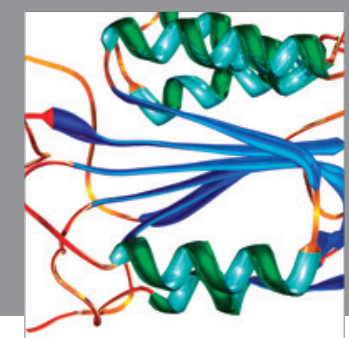

Disease Markers
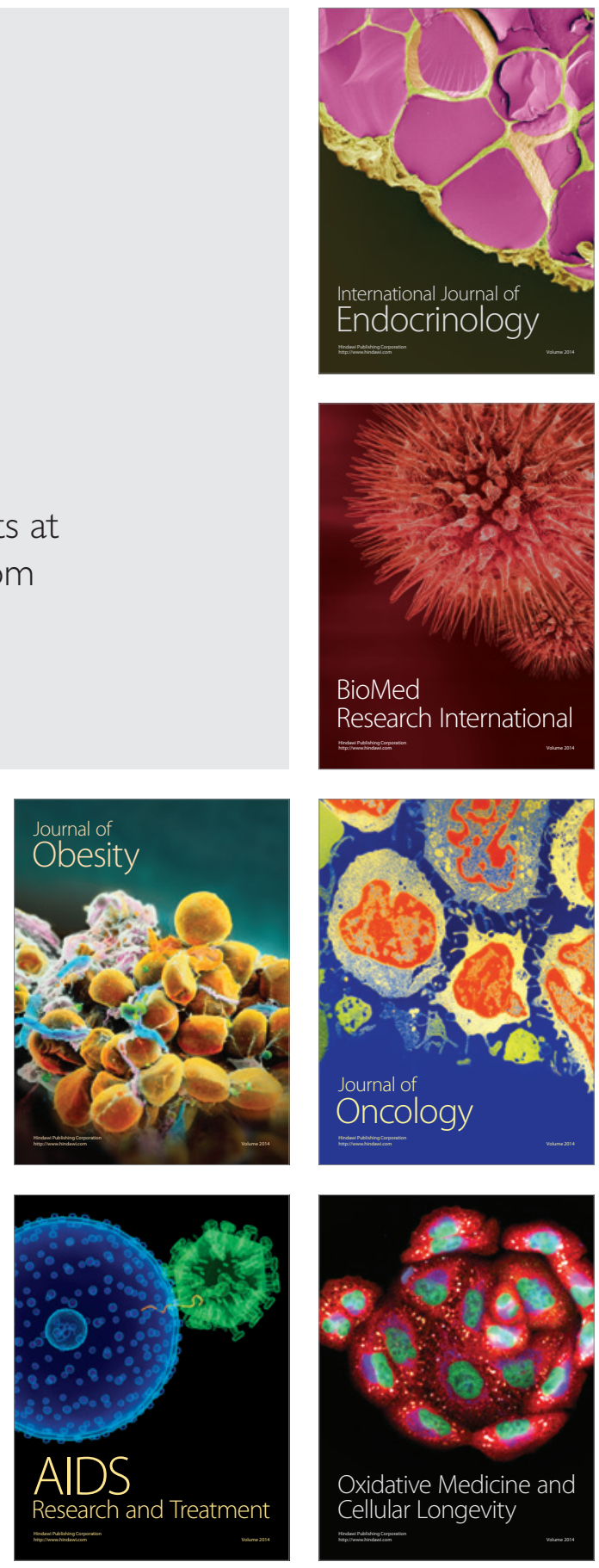